\title{
A CRIAÇÃO DE SI ENTRE A PARRÊSÍA E A HIPOCRISIA: ETOPOIÊTICA DO CUIDADO DE SI
}

\author{
Gustavo Bezerra do Nascimento Costa* \\ arqgustavocosta@hotmail.com
}

RESUMO Esboça-se neste artigo uma possível via de interpretação ao problema ético-estético, ou ainda ético-poiêtico da criação de si, a partir de uma reavaliação da noção de hipocrisia, enquanto arte do engano $e$ arte do

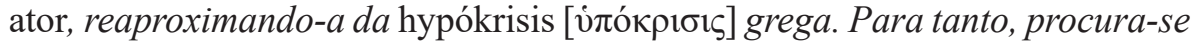
estabelecer um diálogo, ou mesmo um contraponto, com aqueles pensadores que, nas preleções de Foucault, conformaram na antiguidade clássica e helenística os elementos para se pensar, por meio do discurso parrêsiástico e da prática $d a$ áskêsis, a criação de si enquanto estética da existência. O lastro para essa compreensão vem de uma reavaliação das formas de inteligência estocástica e astuciosa que comandam a lida com a inconstância, a multiplicidade e os acasos

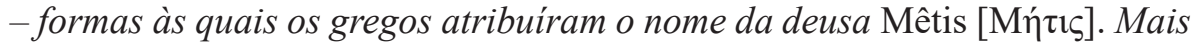
afeitas a estas inconstâncias, práticas tais como: a simulação, a dissimulação e a ênfase - próprias da arte do engano - ganham sob essa ótica uma feição de virtuosidade que o pensamento filosófico hegemônico, afeito à retidão e ao enfrentamento heroico diante do real, dificilmente se disporia a reconhecer.

Palavras-chave Criação de si. Parrêsía. Áskêsis. Hipocrisia. Mêtis.

ABSTRACT This paper outlines a possible way of interpreting the ethicalaesthetic or ethical-poiethical problem of the creation of self, from a re-evaluation of the concept of hypocrisy, while art of deception and the art of the actor,

* UECE. Artigo recebido em 26/12/2015 e aprovado em 16/03/2016.

KRITERION, Belo Horizonte, n 137, Ago./2017, p. 351-371 


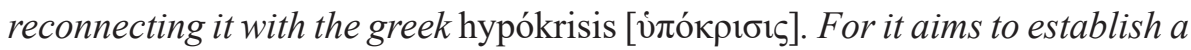
dialogue, or even a counterpoint, with those thinkers who, in Foucault's lectures, conformed in classical and Hellenistic antiquity elements to think, through the parhêsiástic discourse and the practice of áskêsis, the creation of self while an aesthetics of existence. The ballast for this understanding comes from a re-evaluation of forms of stochastic and astute intelligence who command the dealings with the fickleness, the multiplicity and the accidents - which forms the Greeks attributed the name of the goddess Mêtis [Mítıs]. More related to these uncertainties, practices such as: the simulation, dissimulation and the emphasis - related to some art of deception-win under this optics a feature of virtuosity that the hegemonic philosophical thought, wont to the righteousness and the heroic confrontation facing the real, would hardly accept.

Keywords Creation of self. Parrêsía. Áskêsis. Hypocrisy. Mêtis.

Não deixa de soar estranho e provocativo relacionar à gestação de uma vida virtuosa uma noção tal como a de hipocrisia ${ }^{1}$ que, como arte do engano, associa-se ao que, desde Platão e nos diversos modelos éticos, é condenado e desprezado como sinônimo de baixeza e vilania. Uma compreensão inicial acerca do tema da criação de si remete-nos, antes, à tentativa de constituição ética e estética de uma singularidade, pensada em termos de exemplaridade e excelência - tarefa para a qual concorre alguma forma de ascetismo e exercício sobre si, de domínio sobre os próprios instintos. Do homem magnânimo de Aristóteles ao virtuose de M. Onfray, próprio daquele que é digno de grandes

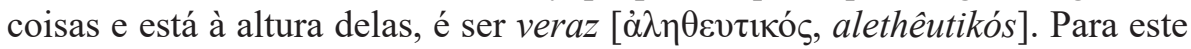
homem virtuoso, é a fala franca, a parrêsía [ $\pi \alpha \rho \rho \eta \sigma i ́ \alpha]$, que é pressuposta tanto na prática da criação de si quanto naquilo que a fomenta: a amizade, enquanto "colaboração [a] uma singularidade completa". ${ }^{2}$ Nesse sentido, como e por que pensar a hipocrisia como meio para uma constituição virtuosa de si?

Em tal defesa está pressuposta uma reavaliação das práticas que, em maior ou menor grau, foram condenadas pelo pensamento filosófico hegemônico:

1 Uma discussão mais aprofundada sobre este tema foi desenvolvida em tese defendida pela Universidade do Estado do Rio de Janeiro. Cf. Costa. "Hipocrisia: arte do engano, arte do ator. Um olhar sobre a criação de si em Nietzsche".

2 Cf. ARISTÓTELES. "Ética a Nicômaco", 1123b a 1125b, Livro IV, 3 e 4, pp. 307-311. Cf. também: ONFRAY. "A escultura de si”, pp. 35ss, p. 135 e pp. 169-174. 
mímêsis, dóxa, prospoiêsis, entre outras, além da própria hypókrisis - a arte do ator. Precisamente por se revestirem de um tipo peculiar de ilusão e engano, o qual se aceita e no qual se deseja permanecer, sofística, poesia e mimética foram os expoentes de uma exclusão ético-pedagógica que tem origem na desqualificação ontológico-moral conduzida pelo pensamento platônico e que perpassa em bloco toda a filosofia moral, demarcando com o fosso fictício da Verdade a separação entre homens e bestas. ${ }^{3}$ Não mais submetidas ao crivo da clivagem entre: verdadeiro e falso, veraz e enganoso, tais práticas reencontrariam lastro nas formas de inteligência estocástica e astuciosa que - seguindo as análises de M. Détienne e J.-P. Vernant - comandam a lida com a inconstância, a multiplicidade e os acasos. Inteligência essa a que os gregos atribuíram o nome da deusa Mêtis - a esposa de Zeus dotada do poder da metamorfose, capaz de revestir-se "das aparências mais diversas". ${ }^{4}$ A mêtis, como afirmam os autores:

[é] uma forma de pensamento, um modo de conhecer; ela implica um conjunto complexo, mas coerente, de atitudes mentais, de comportamentos intelectuais que combinam o faro, a sagacidade, a previsão, a sutileza de espírito, o fingimento, o desembaraço, a atenção vigilante, o senso de oportunidade, habilidades diversas de uma experiência longamente adquirida; ela se aplica a realidades fugazes, móveis, desconcertantes e ambíguas, que não se prestam nem à medida precisa, nem ao cálculo exato, nem ao raciocínio rigoroso. ${ }^{5}$

É no horizonte da mêtis, portanto, que defendo ser possível uma via de interpretação ao problema ético-estético, ou ainda ético-poiêtico da criação de si, a partir de uma reavaliação da noção de hipocrisia - reaproximando-a

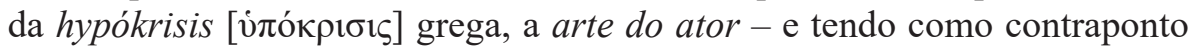
o modelo que, na antiguidade clássica e helenística, segundo as preleções de Foucault, pautara-se pela parrêsía e pela prática ascética.

\section{Mêtis e parrêsía}

A literatura do período helenístico e imperial é farta em obras que concernem à conduta ética de si, seja no dirigir-se ao público, seja nas relações interpessoais. Essa preocupação pode ser remontada aos tratados de Cícero ${ }^{6}$ sobre a oratória e a

6 Referimo-nos aos tratados: "Do orador" e "A amizade". Cf. CíCERO. "Do orador". Trad. Adriano Scatolin. In: SCATOLIN. A invenção no Do orador de Cícero: um estudo à luz de Ad Familiares I, 9, 23. Mas também é possível fazer menção ao seu tratado sobre "A Amizade". Cf. CíCERO. Saber envelhecer seguido de $A$ Amizade. 
amizade, mas também reverbera na tratadística dos secretários do Príncipe e nos moralistas do século XVII. Trata-se, de modo geral, da tentativa de constituição de si a partir da civitas, da conduta civil, fundamental na manutenção das relações sociais e de corte. Conduta essa calcada na oposição entre a amizade e sua pior inimiga: a bajulação - kolakeía, para o grego.

Plutarco, no opúsculo "Da maneira de distinguir o bajulador do amigo", caracteriza o lisonjeador ou bajulador [кó $\lambda \alpha \xi$, kólax] como um ator que se aproveita da vulnerabilidade do lisonjeado, embevecido com sua vaidade, para subjugá-lo e valer-se de seu poder. Fingindo-se amigo, o bajulador dissimula a "semelhança dos gostos que está na origem da amizade". ${ }^{7}$ Hábil em se metamorfosear ao sabor das circunstâncias, assemelhando-se com isso a um camaleão, o bajulador atua segundo uma "técnica que não é de previsão, mas antes, de intuição da oportunidade no momento em que esta se apresenta". ${ }^{8}$ Gostaria de salientar, quanto a isso, dois aspectos que orientarão esta exposição.

O primeiro diz respeito à associação feita por Plutarco, do bajulador à policromia do camaleão. Se nesse tratado ético a analogia é feita sob o viés da condenação, em seu tratado sobre "A inteligência dos animais", 9 é precisamente a habilidade polimórfica de outro animal, o polvo, que é posta em evidência e exaltada. É interessante analisar, quanto a este aspecto, a leitura feita por Détienne e Vernant deste tratado e, de modo geral, do bestiário grego associado às formas de inteligência astuciosa atribuídas a Mêtis. Para os autores, seria necessário

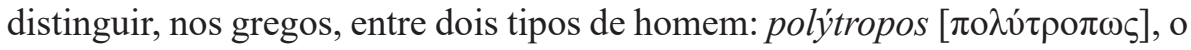
"homem de mil artifícios", e ephêmeros [ $\varepsilon \varphi \eta ́ \mu \varepsilon \rho о \varsigma]$, o "homem dos instantes e das mudanças". Ambos se caracterizariam pela mobilidade, pelo movimento. Porém, enquanto o polýtropos afirma-se por seu domínio: "flexível, ondulante, ele é sempre senhor de si, é instável apenas na aparência”, o ephêmeros, por sua vez, é o homem inconstante, "que se sente mudar a cada instante, experimenta seu ser de fluxo, gira ao menor sopro". Entre ambos haveria a exata distância que separa o polvo do camaleão: "se a metamorfose deste último é produzida pelo medo, a do polvo se deve à astúcia", que se dobra às circunstâncias apenas para dominá-las mais seguramente. ${ }^{10}$

7 Cf. PLUTARCO. Da maneira de distinguir o bajulador do amigo, §1, 48f, p. 27; §5, 51d, p.35; §7, 52e, p.39; $\S 9,53 d$, p.42; §25, 65e-f, p. 80 e $229,69 f$, p.92.

8 Valemo-nos, nesse trecho, dos comentários de Pierre Marechaux ao texto de Plutarco: "As imposturas de Alcibiades ou do camaleão ao sábio estoico". Cf. PLUTARCO. "Como tirar proveito de seus inimigos; Da maneira de distinguir o bajulador do amigo", comentários de Pierre Marechaux, pp. XXII-XXIV.

9 Cf. PLUTARCO. "Sur l'intelligence des animaux" apud DETIENNE; VERNANT. "Métis: as astúcias da inteligência", p. 38ss. Cf. também: Ibidem, p. 46, nota 170.

10 Cf. DETIENNE; VERNANT. "Métis: as astúcias da inteligência", pp. 46-7. 
Cotejada com os textos de Plutarco, tal distinção deixa entrever que, para o grego, condenável não seria propriamente o engano em si, mas ser enganado. E ainda mais: deixar-se enganar pelo próprio ardil e ser vítima da ironia do destino; ou seja, não tomar as rédeas do engano e, como nos versos de Píndaro,

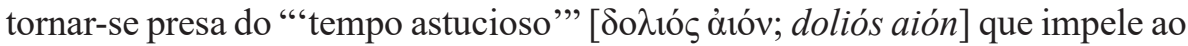
engano $^{11}$ e nos faz vítimas de nosso próprio ardil. Não é por acaso que o polvo - assim como a raposa, cuja "conduta da revirada" usa a estratégia do oponente como sua própria - tenha no pensamento grego o valor de modelo ético, como a encarnação da astúcia no mundo animal. Ressaltando a "inapreensibilidade pelo polimorfismo", ${ }^{12}$ nele se define o comportamento humano da politropia

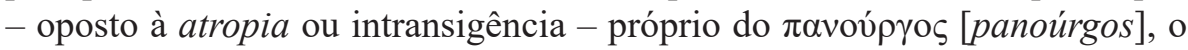
"homem das mil formas", dotado do inquietante prestígio de uma inteligência flexível, ${ }^{13}$ uma "inteligência de tentáculos" que se manifesta, por exemplo, no

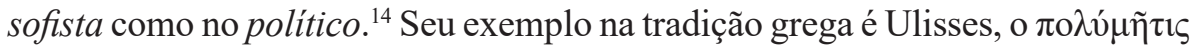
[polýmêtis], mas bem se poderia associá-lo a um referencial antropologicamente mais próximo: o Zé Pelintra - entidade do Catimbó e da Umbanda - e de modo geral, o malandro. Afinal, se, como dizem os dois historiadores, a "mêtis procede obliquamente", ${ }^{15}$ por sua vez, "o malandro anda assim de viés"... ${ }^{16}$

O segundo aspecto que gostaria de salientar no texto de Plutarco diz respeito à percepção, entre as qualidades que confere ao amigo sincero, daquelas mesmas que caracterizariam o lisonjeador "hipócrita": curiosamente - e de certo modo, tal como a raposa do bestiário grego - também o amigo deve saber usar oportunamente a franqueza, fazendo com que a "linguagem livre seja temperada pela maneira de agir e que se submeta às instâncias da razão". ${ }^{17}$ Para ser benéfica e útil ao amigo, "a parrêsía deve ser [...] modelada à conveniência

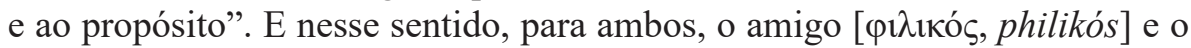
bajulador, a atenção ao kairós mostra-se de extrema valia ao êxito de seus intentos.

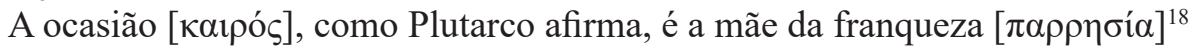

11 Cf. Idem.

12 Cf. Ibidem, p. 39.

13 Cf. Ibidem, p. 277.

14 Cf. Ibidem, pp. $45-8$.

15 Cf. Ibidem, p. 278.

16 Trecho da canção: "A Volta do malandro", composta por Chico Buarque para o filme "A Ópera do Malandro", de 1985, dirigido por Ruy Guerra, com base no musical homônimo de 1978, com composições de Chico Buarque e dirigido por Luiz Antonio Martinez. O musical, como é sabido, é inspirado na "Ópera dos Mendigos" (1728) de John Gray, e na "Ópera dos três vinténs" (1928) de Bertolt Brecht e Kurt Weill (fonte: "Dicionário Cravo Albin da Música Popular Brasileira”, disponível em: http://www.dicionariompb.com.br).

17 Cf. PLUTARCO. "Da maneira de distinguir o bajulador do amigo", §25, 66b, pp. 81-3.

18 Cf. PLUTARCO. "Da maneira de distinguir o bajulador do amigo”, §29, 69e-f, p. 92; e §27, 68c-d, p. 88, respectivamente. 
- mas também o é da lisonja. Com isso, ainda que de modo sutil - como que por politropia - a própria parrêsía, vê-se rendida aos tentáculos do engano.

É em torno desse ponto comum à parrêsía e à mêtis - a atenção ao kairós que passo a discutir de modo mais aprofundado os dois aspectos acima. Agora, seguindo mais de perto algumas preleções de Foucault.

\section{Parrêsía: tékhnê e êthos}

Foucault, como se sabe, é um dos pensadores que reintroduzem na contemporaneidade a questão ético-discursiva da parrêsía, do franco-falar, bem como de seu papel naquilo que chama de "práticas de liberdade"; ou ainda, nos procedimentos de governo de si e dos outros que constituem o indivíduo como sujeito. ${ }^{19}$ Restrinjo aqui esta discussão a dois aspectos: o primeiro deles diz respeito aos modos de transmissão dos discursos de verdade, isto é, ao problema da parrêsía naquilo em que se distingue, por exemplo, do discurso retórico; já o segundo - de que tratarei na seção seguinte - refere-se aos modos pelos quais esse discurso é subjetivado e transformado em um êthos [ń $\theta$ os], ou seja, em um princípio de ação permanente - o que concerne à prática da

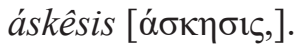

Nas preleções de 1982, a parrêsía é apresentada como uma atitude ética e um procedimento técnico próprio ao discurso filosófico, ${ }^{20}$ cujo específico não seria definido por seu conteúdo, mas pelas regras de prudência e oportunidade sintetizadas na atenção ao kairós. Neste curso, Foucault compreende como um dos traços característicos da Antiguidade entre os séculos I e II, exemplar nas correspondências de Sêneca e Marco Aurélio, a socialização das chamadas práticas de si. Tais práticas consistiriam em um modo de relação entre os indivíduos, fora do âmbito das instituições filosóficas, envolvendo o controle, a formação e o desenvolvimento do indivíduo consigo. ${ }^{21}$ Com ela, ter-se-ia configurado uma nova "ética da relação verbal" fundada na parrêsía, enquanto comportamento "que devemos ter para com o outro na prática da direção de consciência". ${ }^{22}$ Essa nova ética insere-se sobre a superfície do conflito que opõe, durante toda a Antiguidade grega e romana, a filosofia e a retórica; no qual a parrêsía se molda como "forma necessária ao discurso filosófico", que

19 FOUCAULT. "A ética do cuidado de si como prática da liberdade", in: Ditos \& escritos, Vol. V, p. 265. Entrevista com H. Becker, R. Fomet-Betancaurt e A. Gomez-Müller, realizada em 20 de janeiro de 1984, publicada na "Concórdia - Revista Internacional de Filosofia", Nr. 6, pp. 99-116, Julho-Dezembro 1984.

20 FOUCAULT. "Hermenêutica do sujeito", aula de 10 de março de 1982, pp. 449-499, pp. 463-4. Cf. tb.: p. 195.

21 Ibidem, aula de 27 de janeiro de 1982, p. 191ss.

22 Ibidem, aula de 27 de janeiro de 1982, p. 202. 
precisa persuadir e convencer como o retórico, mas que deve, além disso, ser verdadeiro - daí a coragem da qual, em situações-limite, o interlocutor deve se revestir. Nesse sentido, o discurso parrêsiástico deve ser, ao mesmo tempo: "uma técnica e uma ética, [...] uma arte e uma moral". E, como tal, aceitando-se que a retórica não trata do discurso verdadeiro e sim da sedução, o discurso parrêsiástico se assemelharia a uma "retórica não-retórica". ${ }^{23}$

Além de uma atitude ética, portanto, a parrêsía seria também um procedimento técnico. ${ }^{24}$ Foucault apresenta duas vias para essa compreensão. Na primeira via, negativa, o franco-falar se oporia a dois adversários: a lisonja no âmbito moral e a retórica na esfera técnica. Como visto em Plutarco, a parrêsía teria na lisonja não uma mera opositora, mas mesmo uma inimiga. Foucault remete essa animosidade à importância que adquire, no período das monarquias helenísticas e do regime imperial, "a questão da economia das relações de poder em uma sociedade na qual a estrutura da cidade já não era mais predominante". Nesse contexto, ganha relevo a forma ética da cólera enquanto abuso de poder, ou seja, "impossibilidade de exercer o poder e a soberania sobre si mesmo [...] no momento em que se exerce [...] sobre os outros", revelando uma insuficiência de si para consigo. Correlata e complementar à cólera, a lisonja é uma maneira de o inferior "desviar e utilizar em seu próprio proveito o poder do superior", por meio da "única técnica de que pode dispor: o logos". ${ }^{25}$ Com a exacerbação da imagem do poder do superior, o lisonjeador acaba por inverter os papéis, impedindo o lisonjeado de conhecer-se a si mesmo. ${ }^{26} \mathrm{O}$ discurso parrêsiástico se distinguiria da bajulação precisamente porque sua meta não é manter o Outro na dependência de quem fala, mas fazê-lo constituir consigo uma relação autônoma e plena.

Já na esfera técnica, a retórica não seria propriamente uma inimiga, mas uma parceira ambígua da parrêsía, cujas distinções devem ser salientadas. Primeiramente, enquanto na parrêsía "só pode haver verdade", a retórica se caracterizaria pelo "poder de encontrar aquilo que é capaz de persuadir",27 ou seja, uma arte ou técnica da persuasão. Em segundo lugar, enquanto a retórica seria definida pela causa ou assunto tratado, ${ }^{28}$ na parrêsía, é o modo como se deve falar que determinaria a pertinência daquilo de que se fala. Daí

23 Ibidem, aula de 3 de março de 1982, p. 442.

24 Ibidem, aula de 10 de março de 1982, pp. 449-450.

25 Ibidem, pp. 453-4.

26 Ibidem, pp. 457-8.

27 Cf. ARISTÓTELES. "Retórica", Livro I, 1355b, apud. FOUCAULT. "Hermenêutica do sujeito", aula de 10 de março de 1982, p. 460ss.

28 FOUCAULT. "Hermenêutica do sujeito", aula de 10 de março de 1982, p. 463. 


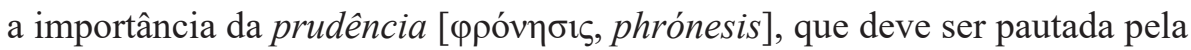
atenção ao momento oportuno - ao kairós - de acordo com o estado de espírito do dirigido. Por fim, embora a parrêsía possa se utilizar da retórica como instrumento casual, já que também tem por função agir sobre os outros, isto é, persuadir, ambas difeririam substancialmente porque enquanto na retórica o peso da fala recairia sobre o falante, em prol da argumentação e do interesse do orador, na parrêsía os polos se invertem e é a generosidade do mestre ante seu discípulo que sobressai, já que o que importa é conseguir que o ouvinte chegue a constituir, por si e consigo mesmo, "uma relação de soberania característica do sujeito sábio, do sujeito virtuoso". ${ }^{29}$

Com relação à via positiva de compreensão da parrêsía, Foucault a reconhece em alguns textos ${ }^{30}$ do período helenístico e imperial que, embora apontando para formas diversas de parrêsía, deixariam entrever elementos comuns: a verticalidade na relação entre o mestre e o discípulo, baseada na exemplaridade e franqueza do mestre; e a horizontalidade entre discípulos, norteada pela benevolência e salvação recíproca. Além disso, como indicado acima, seria possível compreender a parrêsía na dimensão de uma tékhnê e, assim, relacioná-la à especificidade do discurso filosófico como um discurso de verdade. Retomo essa discussão a seguir.

Nas preleções de 1983, a compreensão acerca da parrêsía e de seu estatuto no conjunto dos procedimentos que delineariam o chamado governo de si e dos outros, amplia-se e se torna mais complexa. ${ }^{31}$ Voltando às distinções, em sua dimensão técnica, a parrêsía não se confundiria com a arte de discutir: a erística, nem com a arte de ensinar: a pedagogia, nem ainda com uma arte de demonstrar. Com relação à arte de persuadir, porém, Foucault reconhece novamente que a distinção seria mais complicada. Não só porque o livre-falar "pode e muitas vezes deve utilizar os recursos da retórica", mas também porque, em certos tratados como os de Quintiliano, a parrêsía encontra lugar como uma figura de estilo equivalente a um grau zero da retórica, que consiste em "não utilizar figura alguma". ${ }^{32}$ Ainda assim, retomando quase que integralmente os pontos da argumentação feita em 1982, Foucault considera que as duas não poderiam ser confundidas.

29 Cf. Ibidem, p. 465.

30 Nas aulas de 1982, Foucault concentra-se em três textos: o "Perí parrhesías" de Filodemo, a carta 75 de Sêneca a Lucílio e o texto de Galeno no "Tratado das paixões" - leque que será ampliado nas preleções de 1983 e 1984.

31 Cf. FOUCAULT. "O governo de si e dos outros", pp. 143-4, 160 e 296. São distintas, neste curso, três formas de franco-falar: política, judiciária e moral, além da parrêsía filosófica, que não se limitaria a um modo de discurso, mas tenderia a se confundir com a vida.

32 Cf. FOUCAULT. "O governo de si e dos outros", pp. 52-3. 
É preciso, no entanto, atentar para um duplo deslocamento em relação ao curso do ano anterior: por um lado, o especifico da parrêsía não deve mais ser buscado em sua tékhnê, e, sim, em sua dimensão ética, onde a coragem da verdade põe à prova qualquer aproximação entre ambas; por outro, o foco nesse âmbito passa a ser não mais o interlocutor, aquele que escuta, e sim aquele que fala como um sujeito portador e enunciador de discursos de verdade: o parrêsiasta, que aceita voluntária e explicitamente ser franco, mesmo à custa da própria existência. O específico da parrêsía, a partir destes deslocamentos, não deve ser buscado na estrutura interna, tampouco na finalidade do discurso, naquilo que atinge o interlocutor, e, sim, no efeito de retorno que o dizer-a-verdade vem a produzir no locutor, a partir do efeito produzido no interlocutor. ${ }^{33} \mathrm{De}$ modo mais nítido nas aulas de 1984, o parrêsiasta é apresentado como alguém que, ao dizer a verdade, dá início a uma transformação no êthos do interlocutor. Mas, em contrapartida, assume um risco não calculado, não antecipado, que pode inclusive levá-lo à morte. Esse risco, que deixa entrever muito acerca de seu próprio êthos, revelaria uma experiência de verdade que, segundo Foucault, aparece de forma mais nítida em pelo menos três registros: político, na relação entre Platão e Dionísio de Siracusa; ético, com Sócrates diante da assembleia; e artístico, nos temas das comédias e sátiras da Antiguidade, onde sobressai a figura do cínico como aquele que melhor encarnaria a coragem diante da verdade. ${ }^{34}$

\section{Parrêsía $\mathbf{x}$ retórica, parrêsía $\mathbf{x}$ hypokrisía}

É certo que passam ao largo do projeto foucaultiano, tanto do ponto de vista do enfoque como do método, ${ }^{35}$ discussões como as que proponho. Ainda assim, gostaria de tecer duas ordens de considerações - uma com teor técnico, e a outra, ético - que visam muito mais às consequências extraídas dos autores e textos que são o objeto de suas preleções.

A primeira refere-se à distinção e demarcação de limites precisos entre a parrêsía e a retórica - particularmente, pela importância atribuída, nas preleções de 1982, à noção de kairós. Uma tékhnê define-se, desde Aristóteles, pela "capacidade de produzir que envolve o reto raciocínio" e pela oposição ao necessário, ao espontâneo, ao natural. ${ }^{36} \mathrm{Na}$ parrêsía, esse componente técnico seria o da atenção ao kairós, do cuidado com o momento oportuno à fala franca,

33 Cf. FOUCAULT. "O governo de si e dos outros”, pp. 55-6.

34 Cf. FOUCAULT. “A coragem de verdade: o governo de si e dos outros II”, pp. 157-8 e p. 164.

35 Cf. GROS. Posfácio - Situação do curso. In: FOUCAULT. "A coragem de verdade: o governo de si e dos outros II", pp. 303-316, p. 303ss.

36 ARISTÓTELES. "Ética a Nicômaco", 1140a6-23. 
envolvendo o cálculo prudencial em vista das circunstâncias mais propícias ao proferimento - tangenciando-se, com isso, o campo da retórica. Embora não pareça haver nas preleções de Foucault uma aproximação a partir desse ponto específico, são sugestivas as passagens em que fica clara a compreensão acerca do teor persuasivo da parrêsía - vista inclusive como uma "retórica não-retórica". ${ }^{37}$ Mas até aí, diria Foucault, tratar-se-ia de uma aproximação circunstancial e em nada alteraria a compreensão de ambas como diferentes e opostas. Isto, no entanto, pressuporia que se pudesse valer de uma delas abrindo mão da outra, sem prejuízos - o que, de fato, valeria para a retórica, que serve à franqueza tanto quanto à lisonja. Mas talvez não se possa dizer o mesmo da parrêsía, pois, como já visto em Plutarco, o elemento da atenção ao kairós é condição para que seja bem-sucedida. Estar-se-ia, certamente, no âmbito de uma relação circunstancial; mas de uma circunstância sem a qual a parrêsía perderia sua eficácia, seu poder de persuasão - surtindo, talvez, efeito oposto ao pretendido.

A meu ver, compreender a atenção ao kairós como sendo o específico na dimensão técnica do franco-falar significaria reconhecer, para além da mera ocasionalidade, uma afinidade mais profunda entre a parrêsía e o cálculo prudencial propriamente retórico. Deve-se recordar, com Détienne e Vernant, que é o domínio do kairós, do tempo astucioso, que comanda a confiança do animal na emboscada a sua presa, tanto quanto o sofista e o político nas assembleias. $\mathrm{O}$ enganador também pode valer-se da veracidade, ser franco, apenas com o domínio do momento oportuno para sê-lo. Não por acaso, o domínio do kairós é necessário também à eficácia da kolakeía, a grande "inimiga" da parrêsía - só a indiferença, afinal, prescinde da prudência. Parrêsía e kolakeía, nesse sentido, não estariam tão distantes uma da outra, a não ser pela intenção de causar ou não algum dano. Mas aqui, Foucault o viu muito bem, já não se estaria mais no âmbito da tékhnê e sim na esfera ética. E, com isso, entro na segunda ordem de considerações.

Nas preleções de 1983 e 1984, se por um lado o franco-falar ganha em complexidade e aprofundamento, por outro, justamente o "nó" da problemática acerca da distinção entre parrêsía e retórica: o componente técnico-prudencial da atenção ao kairós na transformação do interlocutor, acaba por ser preterido ${ }^{38}$ em favor da dimensão ética e do elemento da coragem e risco do locutor ao ser

37 Cf. FOUCAULT. "Hermenêutica do sujeito", aula de 10 de março de 1982, p. 468.

38 FOUCAULT. "O governo de si e dos outros", pp. 204, 207 e 312. As referências ao kairós são feitas unicamente nas aulas de 9 e 16 de fevereiro e de 9 de março de 1983, e dizem respeito, principalmente, à atenção de Platão quanto ao momento propício de persuadir o monarca Dionísio de Siracusa, no sentido da união entre o exercício filosófico e o exercício do poder. 
franco - donde o exemplo da parrêsía cínica. Aqui se poderiam colocar três questões: primeiramente, até que ponto o discurso de verdade do parrêsiasta prescindiria do cálculo prudencial relativo ao kairós - cuja importância fora acentuada já por Plutarco - em nome da verdade desinteressada e implicando risco de morte, sem que, chegando a esse limite, acabe por atestar a sua própria ineficácia quanto ao propósito de transformar o interlocutor? Depois, até que ponto a parrêsía, em nome da qual o locutor arrisca a própria vida e transforma também a si, não implicaria de sua parte, um trabalho de reflexão, ascese e autoexperimentação, diante do qual já não fariam sentido noções caras ao cinismo, como, por exemplo, a espontaneidade e a "decapagem ao elementar da existência"? ${ }^{39}$ Por fim, como pensar a franqueza cínica quando esta implica algum tipo de autoexperimentação e o exercício da ponderação?

Aceitando-se a pertinência destas questões, o cinismo, com seu desafio ético de incorporar ao limite as verdades recebidas pelo discurso parrêsiástico, permaneceria certamente no extremo oposto à lisonja, que visa ao prejuízo do interlocutor e à manutenção de um estado de dependência perniciosa entre ambos - distanciando-se com isso de uma criação virtuosa de si. Porém, não se poderia dizer o mesmo no que diz respeito ao manejo deliberado de crenças que caracteriza a hipocrisia, bem como no que tange ao trabalho do ator na preparação de seu personagem. Aqui, certa ótica de espectador, atenta apenas ao efeito de cena, acaba por elidir uma compreensão mais aprofundada acerca desta arte, a que os gregos denominavam íđókpıбıৎ [hypókrisis]. Com ela, não me refiro apenas à mera manipulação de impressões e imitação de tipos, mas, principalmente, à experimentação e manuseio de si consigo, próprios do ator, do i̇oкрıт́́s [hypokritês], no preparo de seu personagem. ${ }^{40}$ Bem mais que experimentar a verdade nos outros - e a dos outros - o ator, o hipócrita precisa, tal qual o cínico, forjá-la em si próprio. Com a ressalva de que, diferentemente daquele, cada personagem, enquanto configuração distinta de acasos, requer do ator uma nova modelagem, um novo trabalho de si sobre seus próprios instintos. Ao passo que ao cínico, que se mostra preso a um discurso de verdade reinventado "pela imaginação e pela meditação", ${ }^{41}$ submetendo a esse discurso a experiência de si, a ele restaria o enfrentamento heroico e temerário diante

39 Cf. FOUCAULT. "A coragem de verdade: o governo de si e dos outros II", p. 164.

40 Esse é um dos pontos centrais da tese que defendi em 2013 pela Universidade Estadual do Rio de Janeiro. Cf. COSTA. "Hipocrisia: arte do engano, arte do ator. Um olhar sobre a criação de si em Nietzsche". Cf. particularmente: a retomada da concepção grega de hypókrisis como atuação (p. 51ss.) e a contraposição feita entre duas posturas acerca da arte do ator: a que permeia o "Paradoxo sobre o comediante", de Diderot (1769) e a que é defendida no início do século XX por Stanislavski (p. 165ss.).

41 FOUCAULT. "O governo de si e dos outros", p. 236. 
do real - à custa, porém, do autoengano e da extirpação dos próprios instintos. A morte seria aqui o corolário nobre, virtuoso, da coragem e heroísmo ante as consequências da franqueza - uma experiência de verdade, portanto - o que certamente diz muito acerca do parrêsiasta cínico. Mas, também, pode ser a decorrência de um processo malfadado de transformação do êthos do locutor.

\section{Áskêsis: a ética do cuidado de si}

Feitas estas considerações, procuro agora compreender os processos pelos quais o discurso filosófico, parrêsiástico, será então incorporado e convertido em um $\eta \dot{\theta} \operatorname{os}$ [êthos], configurando na Antiguidade clássica e tardia aquilo que Foucault chama de práticas de liberdade. Como ele bem expõe, para o grego, a filosofia significava também "certa relação prática consigo mesmo pela qual você elabora a si mesmo e trabalha sobre si mesmo". ${ }^{42} \mathrm{O}$ princípio destas práticas

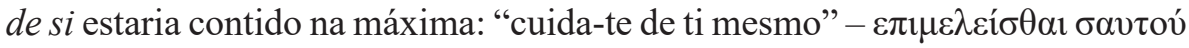
[epimeleísthai sautoú]. E requereria não apenas a atenção ao princípio délfico:

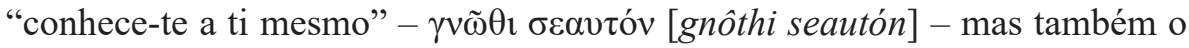
incorporar regras de conduta, vinculando-se assim a um determinado jogo de verdade. ${ }^{43}$

Em "Les techniques de soi", Foucault aponta para duas elaborações filosóficas desse cuidado de si na Antiguidade. ${ }^{44}$ A primeira delas ter-se-ia iniciado com o "Alcibíades" de Platão, onde o cuidado de si aparece como "ponto de junção" entre a ambição política e o amor filosófico. Trata-se, nessa primeira elaboração, não do cuidado com o corpo, ${ }^{45}$ mas, sim, daquilo que dá ao corpo a sua atividade: a alma. E, para cuidar da alma, seria preciso compreendêla como semelhante a um "espelho" para a contemplação do elemento divino, através do qual descobrirá regras para "um comportamento e uma ação política justas". " Já a segunda elaboração adviria de sua universalização durante o período helenístico e romano, particularmente com Epicuro e os epicuristas,

42 FOUCAULT. "O governo de si e dos outros", aula de 9 de fevereiro de 1983, p. 200.

43 FOUCAULT. "A ética do cuidado de si como prática da liberdade". In: Ditos \& escritos, Vol. V, pp. 267-8.

44 Cf. FOUCAULT. "Les Techniques de soi". In: Dits et écrits, Vol. IV, pp. 786-7. Segundo Foucault, a tradição filosófica iniciada com Platão teria operado uma inversão na hierarquia entre os dois princípios do cuidado de si e do conhecimento de si, constituindo a este como fundamental, deixando de lado o vínculo com o primeiro. Dois teriam sido os motivos, segundo ele, para esse "esquecimento": primeiramente a "profunda transformação" nos "princípios morais da sociedade ocidental", com a herança da moral cristã "que faz da renúncia de si a condição da salvação" e, paradoxalmente, tem no conhecer-se a si mesmo um meio para renunciar a si mesmo. Em segundo lugar, a importância que a máxima délfica adquire, na filosofia teórica que vai de Descartes a Husserl, como "ponto de referência da teoria do conhecimento".

45 Cf. FOUCAULT. "Hermenêutica do sujeito", aula de 27 de janeiro de 1982, p. 200.

46 FOUCAULT. "Les techniques de soi”. In: Dits et écrits, Vol. IV, pp. 790-3. 
os cínicos e alguns estoicos como Sêneca, Rufus e Galeno. As diferenças para a primeira elaboração girariam em torno de quatro grandes ${ }^{47}$ problemas ou eixos, que envolvem a relação do cuidado de si com: a atividade política; a pedagogia; o conhecimento de si; e, por último, o amor filosófico - ou seja, a relação com um mestre. Interessa mais de perto o terceiro eixo ou problema, que diria respeito de modo mais direto ao problema da ó $\sigma \kappa \eta \sigma ı \varsigma$ [áskêsis].

Se, em Platão, cuidar do corpo não seria tão importante quanto cuidar da alma, com essa segunda elaboração, ao contrário, a ênfase no "cuida de ti mesmo" será direcionada a três domínios: dietética, econômica e erótica-que serão a partir daqui reintegrados à superfície de reflexão como uma "ocasião [...] para o próprio eu experimentar-se, exercer-se, desenvolver a prática de si mesmo que é sua regra de existência e seu objetivo". Esses três domínios que, segundo Foucault, aparecem exemplarmente nas correspondências de Sêneca e Marco Aurélio, mas também em Epíteto, Cícero e Plutarco, constituem-se então como os "domínios de aplicação da prática de si" ${ }^{48}$ Como afirma em "Les techniques de soi", emerge, como esse novo cuidado de si, também uma nova experiência de si, voltada aos detalhes da vida cotidiana e à análise de si por meio da introspecção - o que estaria amparado em uma relação entre escrita e vigilância efetivada por meio de duas técnicas: as cartas aos amigos, naquilo que revelam de si, e o exame de si mesmo, como avaliação daquilo que foi ou deveria ter sido feito. ${ }^{49} \mathrm{Com}$ algumas distinções, essas duas técnicas reaparecem em "A escrita de si" como componentes do que Foucault chama de escrita etopoiêtica, presente nos hypomnêmata, anotações fragmentárias obtidas "a partir da coleta do discurso dos outros", e nas epístolas, enquanto relato e decifração escrita de si mesmo. ${ }^{50}$

A terceira técnica, ${ }^{51}$ também exposta em "Les techniques de soi", diria respeito aos atos de rememoração visando não à descoberta da verdade no indivíduo, mas à subjetivação daquela verdade contida nos preceitos dos mestres - os lógoi -, intensificando com isso a própria subjetividade. Trata-se,

47 Ibidem, pp. 792-5.

48 FOUCAULT. "Hermenêutica do sujeito", aula de 27 de janeiro de 1982, p. 200.

49 FOUCAULT. "Les techniques de soi". In: Dits et écrits, Vol. IV, pp. 798-9. Cf. também: pp. 792-3: "Presta-se atenção às nuanças da vida, aos estados da alma e à leitura, e o ato de escrever intensifica e aprofunda $a$ experiência de si. Todo um campo de experiências que não existia anteriormente se abre".

50 FOUCAULT. "A escrita de si". In: Ditos \& escritos, Vol. V, pp.147-162.

51 Enquanto em "A escrita de si" as duas técnicas anteriores, relativas à escrita etopoiêtica, aparecem como componentes da áskēsis, em "Les techniques de soi" Foucault as apresenta como três técnicas distintas. Cf. FOUCAULT. "A Escrita de si". In: Ditos \& escritos, Vol. V, p. 146. Nesse sentido, talvez pudéssemos falar de duas noções de ascese, em sentido estrito, como componente técnico das práticas do cuidado de si, e em sentido lato, referindo-se às próprias práticas. A esse respeito, cf. também: FOUCAULT. "O governo de si e dos outros", aula de 9 de fevereiro de 1983, p. 200. 
enfim, da áskêsis, que compreende certo número de exercícios nos quais "o sujeito se coloca na situação de verificar se é capaz ou não de fazer face aos acontecimentos e de utilizar o discurso do qual está armado". ${ }^{52}$ Diferentemente da acepção cristã, que se aproximaria de uma forma de renúncia, ${ }^{53}$ a áskêsis implicaria, principalmente na tradição estoica, a "consideração progressiva de si" na preparação para "uma maestria à qual se alcança não pela renúncia à realidade, mas ao se obter e assimilar a verdade". ${ }^{54}$ A palavra grega que descreve essa atitude é: $\pi \alpha \rho \alpha \sigma \kappa \varepsilon v \alpha ́ \zeta \omega$ [paraskeuázô] - "preparar-se" - sendo

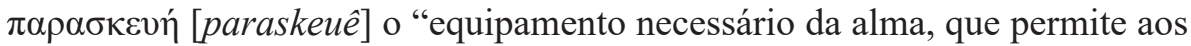
indivíduos enfrentar [...] todos os acontecimentos da vida na medida em que eles se apresentem". ${ }^{55}$

Aáskêsis, então, diria respeito ao conjunto de práticas pelas quais o indivíduo poderia assimilar a verdade de um discurso - do discurso parrêsiástico - e convertê-la em um princípio de ação permanente - isto é, em um ń日os [êthos]. Dois termos - ambos, a meu ver, associados a formas de ponderação e simulação - exprimiriam os polos dessa prática: $\mu \varepsilon \lambda \lambda \eta \tau \eta ́$ [melletê] e $\gamma v \mu v \alpha ́ \sigma 1 \alpha$ [gymnásia]. No que diz respeito à primeira, a meditatio para os latinos, consiste em antecipar a situação real por meio do diálogo dos pensamentos. ${ }^{56}$ Quanto à segunda, a gymnásia, corresponderia ao entretenimento e exercício que, diferentemente da experiência imaginária da melletê, envolve uma situação real, ainda que induzida artificialmente. ${ }^{57}$ Em torno desses dois polos se configuraria a prática da áskêsis, que em conjunto com a escrita etopoiêtica caracterizaria o cuidado de si no decorrer dos períodos helenístico e romano.

Em "O uso dos prazeres e as técnicas de si", essas práticas de si são analisadas em função da moralidade, compreendida como a maneira pela qual os indivíduos se submetem "a um princípio de conduta, [...] pela qual respeitam ou negligenciam um conjunto de valores". ${ }^{58}$ Para Foucault, a atenção com o

52 FOUCAULT. "Les Techniques de soi". In: Dits et écrits, Vol. IV, pp. 798-9.

53 Cf. FOUCAULT. "Les techniques de soi”. In: Dits et écrits, Vol. IV, p. 810.

54 FOUCAULT. "Les techniques de soi". In: Dits et écrits, Vol. IV, p.798-9.

55 FOUCAULT. "Hermenêutica do sujeito", aula de 17 de março de 1982, p. 504.

56 Ou seja: "imaginar como se articulam diversos acontecimentos possíveis a fim de experimentar de qual maneira se reagiria”. Cf. FOUCAULT.“Les techniques de soi”, p. 799. Cf. também: CHANTRAîNE. "Dictionnaire

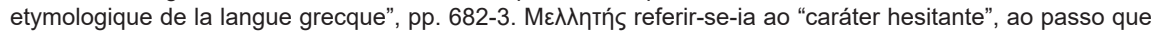

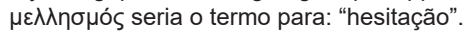

57 Teria surgido daqui, aliás, uma longa tradição de práticas envolvendo a abstinência sexual, a privação física e outros rituais de purificação, com a função "de estabelecer e de testar a independência do indivíduo em relação ao mundo exterior". Cf. Ibidem, p. 800. Cf. também: FOUCAULT. "Hermenêutica do sujeito", aula de 17 de março de 1982.

58 FOUCAULT. "O Uso dos prazeres e as técnicas de si". In: Ditos \& escritos, Vol. V, pp. 192-217, p. 211. Uma moralidade dos comportamentos, nesse sentido, determinaria "de que modo, e com que margem de variação ou de transgressão, os indivíduos ou grupos se conduzem em referência a um sistema prescritivo, que é explicitamente dado em sua cultura, e do qual eles têm consciência mais ou menos clara" (idem). 
problema de organização de existência e com o cuidado de si ganha relevo no momento em que uma moral, enquanto obediência a um sistema prescritivo, já não se mostra efetiva. Um ń $\theta$ os [êthos], portanto, uma ética pessoal concebida como uma maneira de ser e de organizar a própria existência, toma forma na medida em que a obediência a um "̌̈0 0 [éthos], a um código de regras estabelecido fenece, daí o seu viés transgressor: "a esta ausência de moral [...] deve corresponder uma busca que é aquela de uma estética da existência". ${ }^{59}$

Redefinindo, portanto, os limites da ética no período helenístico e romano, concebendo-a como uma "prática refletida da liberdade", ${ }^{60}$ Foucault aproxima-a da contemporaneidade na forma de uma estética da existência: noção que implica uma ética, na medida em que êthos (com eta) diz respeito à maneira de ser e de conduzir-se em coexistência e por vezes contraposição a um éthos (com épsilon), a um código moral estabelecido; mas que também possui uma dimensão artística ou poiêtica, já que implica uma nova e muitas vezes transgressora experiência de reflexão, manejo e domínio de si, em face do acaso e das regras estabelecidas - daí a proposta de criação de si como obra de arte. ${ }^{61}$

\section{Criação de si como exercício de hipocrisia}

Retorno à pergunta feita no início deste texto: como e por que pensar a hipocrisia como meio para uma constituição virtuosa de si? Pretendo respondêla a partir dos pontos de aproximação e afastamento que, a meu ver, poderiam ser tecidos em relação à etopoiêtica apresentada por Foucault - reconhecendo desde já a distância em relação a método, enfoque e propósitos. ${ }^{62}$

É bem certo que, com a leitura aqui feita, da hermenêutica foucaultiana acerca dos processos de subjetivação e constituição de si na Antiguidade, terse-ia, talvez, mais aproximações que distanciamentos em relação à tentativa de se compreender a criação de si como exercício de hipocrisia. Com efeito, pelo menos dois aspectos poderiam ser salientados: o primeiro deles foi discutido

59 FOUCAULT. "Uma Estética da existência”. In: Ditos \& escritos, Vol. V, pp. 288-293, p. 290. Entrevista com A. Fontana (Le Monde).

60 FOUCAULT. "A Ética do cuidado de si como prática da liberdade". In: Ditos \& escritos, Vol. V, p. 267.

61 Em entrevista a H. Dreyfus e P. Rabinow, Foucault afirma: "O que me surpreende é o fato de que, em nossa sociedade, a arte tenha se transformado em algo relacionado apenas a objetos e não a indivíduos ou à vida [...]. Mas a vida de todo indivíduo não poderia ser uma obra de arte? Por que uma mesa ou uma casa são objetos de arte, mas nossas vidas não?". Cf. FOUCAULT. "À propos de la généalogie de l'éthique" apud DIAS. "Nietzsche e Foucault - a vida como obra de arte", p. 49.

62 Cf. GROS. Posfácio - Situação do curso. In: FOUCAULT. "A coragem de verdade: o governo de si e dos outros II", p. 313ss. Para Gros, a proposta foucaultiana de constituição de si com base no binômio: coragemverdade, deve ser pensada conjuntamente a uma atitude política vinculada não a uma moral, mas a uma ética do engajamento intelectual. 
anteriormente e diz respeito ao problema da atenção ao kairós na constituição da parrêsía como discurso autônomo em relação à retórica - pelo que sugiro ver no discurso parrêsiástico um modo mais bem elaborado - e talvez autoenganado, isto é, não reconhecido ${ }^{63}$ - de discurso retórico, com o refinamento das formas de engano e manipulação de crenças aí contidas. Já o segundo pode ser depreendido da seção anterior e concerne à compreensão dos processos de subjetivação como uma paraskeué, ou seja, um princípio de ação movido pela áskêsis. Tais processos, como defendo, poderiam ser aproximados das técnicas de manuseio de si que caracteriza a arte do ator, no processo de incorporação de um personagem.

Uma aproximação desse tipo aparece já nas análises sociológicas de Erwin Goffman e Richard Sennet, que tomam a arte do ator como imagem para as formas de constituição, interação e resistência do indivíduo ante a sociedade. Outra abordagem, porém, é a que tomo como objeto de minha tese, cujo cenário se esboça a partir de uma dupla compreensão da relação entre hipocrisia - enquanto arte do engano e da manipulação - e autoengano - enquanto assimilação não reconhecida de crenças. Primeiramente, com base em uma distinção formal de perspectivas, que põe em lados opostos: o enganado, que desconhece o engano e por vezes sofre com os prejuízos aí advindos, e o enganador, que tem no reconhecimento a condição para a manipulação de crenças - inclusive as próprias. Depois, como uma transição gradativa, processual, que tem o autoengano como decorrência de práticas refinadas, embora não reconhecidas, de engano ou manejo de si, visando à incorporação de caracteres pela assimilação de crenças e cultivo dos próprios instintos. Práticas essas que, como defendo, teriam o ator como exceção capaz de transpor caracteres sem se fixar em um deles.

O mote para essa abordagem, destarte, é o de uma compreensão mais detida acerca da arte do ator, a partir do contrassenso posto por Diderot em "Paradoxo sobre o comediante": "Se ele é ele quando representa, como deixará de ser ele? Se ele quer cessar de ser ele, como perceberá o ponto justo em que deve colocarse e deter-se?". ${ }^{64}$ De que maneira, portanto, seria possível ao ator, mestre na arte de imitar, passar tão bem de uma imitação a outra mantendo a ilusão desejada pelo público, sem, no entanto, expor-se ele próprio ao autoengano, ou seja, sem que lhe seja necessário iludir-se e submeter-se à crença em seu personagem?

63 Cf. PALMA. "As (des) razões da irracionalidade: uma análise conceitual do autoengano, da consciência inconsciente e de outros paradoxos do discurso psicanalítico", pp. 39-53. A partir das críticas à chamada teoria da bicompartimentação, uma outra interpretação é apresentada pelo autor, na qual o autoengano é visto como um processo não reconhecido de assimilação de crenças, cujo grau de incorporação variaria de acordo com a força inercial da crença a ser substituída.

64 DIDEROT. "Paradoxo sobre o comediante", p. 163. 
Esta questão, procuro analisá-la e respondê-la em três desdobramentos: ${ }^{65}$ 1) na dimensão atuante, ou actante, da arte retórica de Quintiliano, tendo a hypókrisis como uma de suas figuras; 2) na teoria de Stanislavski acerca da formação do personagem a partir do cultivo de seus próprios instintos; e 3) na correlação feita por Lacoue-Labarthe entre a mimese teatral e a mimese geral - a poíêsis artística em sentido amplo -, culminando na crítica e suposta impropriedade do mimetizador, ou seja, sujeito-autor, em relação àquilo que chama de pura máscara ou pura hipocrisia. ${ }^{66}$

Não seria o caso aqui de percorrer a fundo tais desdobramentos, mas cabe salientar que os dois primeiros apontam, entre outros aspectos, para a compreensão de que a arte do ator - a hypókrisis, para o grego - não se resume ao controle dos artifícios utilizados na atuação, ou seja, do efeito de cena visando à ilusão do espectador. Não se trata meramente de uma arte da administração de impressões, mas, sobretudo, do exercício, de certo modo ascético, de preparação - a paraskeuê grega - de si como personagem. No caso de Diderot, pela incorporação de caracteres com base em um modelo ideal, até que se chegue ao estado de extenuação, chamado blasés ${ }^{67} \mathrm{em}$ que o ator se identifica com seu personagem. E em Stanislavski, no cultivo dos próprios sentimentos pelo exercício da imaginação e, porque não, da phantasía. Naquilo que difere do autoengano, portanto, o trabalho de convencimento de si do ator revela um aspecto da hipocrisia que parece extrapolar os limites da avaliação moral radicada na perspectiva do espectador - isto é, do enganado, e não do enganador - atenta apenas aos efeitos da ilusão sofrida, sejam eles benéficos ou não. Tal ótica elude precisamente o trabalho de manuseio ou manipulação de sienvolvendo a antecipação e autoexperimentação, a melletê e a gymnásia, isto é, a áskêsis - que se poderia considerar da maior importância para a compreensão da pauta etopoiêtica de criação de si como um exercício de hipocrisia.

\section{Cinismo x hipocrisia}

Mas se podem ser tecidas aproximações entre esta concepção e aquela apresentada por Foucault, em contrapartida, pelo menos dois pontos importantes tornariam problemática a ideia de um cuidado de si e de uma estética da existência radicados no discurso parrêsiástico e na áskêsis filosófica. O primeiro

65 Cf. COSTA. "Hipocrisia: arte do engano, arte do ator. Um olhar sobre a criação de si em Nietzsche", seções 2.6 a 2.8 , pp. 159-190.

66 Cf. LACOUE-LABARTHE. "A imitação dos modernos”, pp. 169-170.

67 DIDEROT. "Paradoxo sobre o comediante", p. 186. 
deles, que de certa forma transcende o que foi apresentado por Foucault e nos aproxima do pensamento de Nietzsche, diria respeito a que o horizonte de uma criação hipócrita de si é o de uma grande dietética. ${ }^{68}$ Nesse ponto, seguindo Pierre Hadot, ${ }^{69}$ a criação de si nietzscheana distancia-se daquilo que os antigos compreendiam como cuidado de si. É certo que se poderiam associar a ela as práticas da escrita etopoiêtica e da áskêsis, visando à configuração de um princípio de ação permanente, ou de um êthos. Entretanto, haveria um afastamento não apenas quanto aos meios aí empregados: não se pressupõe em Nietzsche uma erradicação das paixões, mas seu cultivo, domesticação ou superação; como também em relação à origem dos “dados” para essa criação: não se trata da subjetivação de um discurso parrêsiástico, mas da atenção aos próprios impulsos, aqui "subjetivados", isto é, ficcionados pelos processos conscientes na forma de opiniões e desacertos.

Quanto ao segundo ponto, mais diretamente voltado à criação de si radicada na parrêsía e na áskêsis, e sobre o qual me deterei um pouco mais, poder-seia apresentá-lo na forma imagética de uma contraposição entre a fixidez e a inconstância. Com efeito, como poderiam regras e princípios previamente traçados a partir da experiência e da prescrição, e transmitidos por meio de um discurso de verdade, convencer o corpo enquanto configuração instável de instintos e enfrentar os acontecimentos enquanto configuração instável de acasos? Pautado pela inflexibilidade da regra transmitida pelo discurso parrêsiástico, o trabalho de ascese não se mostraria eficaz, por exemplo, na lida com situações de instabilidade e inconstância, que não são poucas, em que se requer não o atuar conforme prescrições, mas antes, o improviso. Não por acaso, ao cínico restaria apenas o enfrentamento heroico, porém, quase sempre autoenganado, diante da verdade, do real - com a presença não tão discreta, nessa lida, das ideias de enfrentamento e extirpação.

Como afirmam Détienne e Vernant: "para o grego, só o mesmo age sobre o mesmo". ${ }^{70} \mathrm{E}$, nesse sentido, se é necessária uma áskêsis, se é necessário converter prescrições em um princípio de ação, ela não poderia ser regida pelo logos racional, mas pela forma de inteligência conjuntural, prudencial e astuciosa,

68 NIETZSCHE. "Ecce homo", II§8, pp. 46-8.

69 Cf. HADOT. "O que é a filosofia antiga?", p. 344. Para Hadot, se há algo em que a criação de si nietzscheana difere da "atenção a si mesmo" dos antigos - envolvendo "um domínio, um controle de si, que só se pode obter pelo hábito e pela perseverança nas práticas ascéticas" - essa diferença está em que, enquanto nos antigos as práticas ascéticas estão "destinadas a realizar o triunfo da razão sobre as paixões, atacadas até a sua erradicação radical”, isto é: a apatheia, para Nietzsche, ao contrário, trata-se antes de cultivar os instintos, tornando-os plenos. Cf. NIETZSCHE. "Sämtliche Werke: Kritische Studienausgabe" (KSA), Vol. X:4[169]18823, p. 161: "Finalidade do ascetismo: deixar a própria sede crescer, a criação pessoal precisa represar-se".

70 DETIENNE; VERNANT. "Métis: as astúcias da inteligência", p. 27. 
que desde o século IV da outra era tem permanecido à margem do discurso filosófico, mas que desde Hesíodo tece os liames para a lida com o acaso:

Precedendo o kairós tão rápido ele seja, é a mêtis que desempenha contra ele o efeito da surpresa; ela pode "apreender" a ocasião à medida que, não sendo "leve", ela souber prever a continuação dos acontecimentos e preparar-se de mais longe. ${ }^{71}$

Essa arte de exercitar-se para o acaso por meio da mêtis - ou seja, de incorporar, por meio da simulação, dissimulação e ênfase, um saber da inconstância advindo dos acasos e instintos - não para enfrentá-lo, mas para, reconhecendo a sua superioridade, a ele moldar-se - sendo essa a forma de subjugá-lo -, essa arte, própria do polýtropos [ $\pi \mathrm{o} \lambda \hat{\tau} \tau \rho-\pi \omega \varsigma]$, daquele que é mestre em driblar, improvisar e adaptar-se às circunstâncias, tem um nome: hipocrisia .

\section{Amizade e hipocrisia}

Vimos no início deste texto o quanto a amizade vem a contribuir para aquilo que, desde Aristóteles, compreende-se como a constituição de uma singularidade virtuosa. Mas o que dizer, à guisa de excurso, de sua aparente distância em relação às práticas que aqui entendemos como hipócritas? Como entender, afinal, uma amizade hipócrita?

Certamente, vejo a amizade como um dos limites à hipocrisia, se a compreendemos como um cativeiro, no sentido de que, nela, cativa-se e se é cativado - pra brincarmos com os dois sentidos da palavra, que talvez sejam um só. Na amizade, o espírito já cativo deixaria de lado o engano para firmar seu caráter do lado do autoengano, ao passo que a hipocrisia implicaria sempre ir de encontro à confiança, à responsabilidade e à própria integridade física. Seria preciso, então, reconhecer que, quanto mais fiel a amizade, quanto mais cativo o espírito, quanto mais forte uma determinada configuração de instintos, mais a arte do ator e do engano deve ceder lugar à espontaneidade, tal qual uma obra de arte, depois de acabada, parece ser, ela mesma, natural - ou mesmo inautoral.

Esse limite da hipocrisia seria bastante preciso se entendêssemos como possíveis apenas as amizades constituídas de forma espontânea - ou seja: inartísticas, em sentido amplo - deixando de lado o trabalho, de certo modo poiêtico, de modelagem de si e do outro, que exige algum grau de acomodação mútua e implica, por sua vez, algum exercício de ênfase em determinados aspectos, dissimulação e mesmo simulação de outros tantos, visando à conquista 
e ao cativeiro - no melhor sentido da palavra. Nesse sentido, se entendermos que a prudência e a atenção ao kairós, ao tempo oportuno, importam tanto para com amigos como para com inimigos, seria preciso reconhecer, talvez, a hipocrisia presente no próprio cuidado, não só com a criação, mas com a manutenção e o fortalecimento de relações de amizade. Feições hipócritas como o senso da oportunidade e a medida da palavra são, muitas vezes, de extrema valia à amizade. Quem em sã consciência, por exemplo, iniciaria uma relação amorosa expondo suas mais cruas e libidinosas intenções, senão como um efeito de cena? $\mathrm{Ou}$, ainda, despejando escatologias, senão como efeito de cena?

Diferentemente do que se costuma imaginar, portanto, uma amizade sincera, "verdadeira", por assim dizer, não pressupõe uma aceitação incondicional e desmedida das espontaneidades de cada um, mas antes, um trabalho de reeducação no sentido do encontro, em um nível outro que já não é o da espontaneidade, mas o da autenticidade. Claro, não se trata de compreender todas as relações interpessoais sob o viés do cálculo prudencial, até porque não poderiam ser reduzidas unicamente a essa bipolaridade. Há uma gama infinita de relações que não passa por esse crivo porque não envolve os "iguais", tampouco os "diferentes", mas aqueles que sempre nos escapam: os indiferentes. De todo modo, para ambos, amigo e inimigo, valeria o que canta mais uma vez Chico Buarque: "qualquer desatenção, faça não, pode ser a gota d'água"...72

\section{Referências}

ARISTÓTELES. “Ética a Nicômaco”. In: Aristóteles. Tradução de L. Vallandro; G. Bornheim. São Paulo: Abril Cultural, 1973. Coleção Os Pensadores.

CHANTRAÎNE, P. "Dictionnaire étymologique de la langue Grecque". Paris: Klincksieck, 1999.

CÍCERO. "Do orador". Tradução de A. Scatolin. In: SCATOLIN, A. A invenção no Do orador de Cícero: um estudo à luz de Ad Familiares I, 9, 23. 2009. 308f. Tese (Doutorado em Letras Clássicas e Vernáculas). Universidade de São Paulo, São Paulo. . "Saber envelhecer seguido de A Amizade". Tradução de P. Neves. São Paulo: L\&PM Pocket, 1997.

COSTA, G. "Hipocrisia: arte do engano, arte do ator. Um olhar sobre a criação de si em Nietzsche". 2013. 310f. Tese (Doutorado em Filosofia). Universidade Estadual do Rio de Janeiro, Rio de Janeiro.

DETIENNE, M.; VERNANT, J.-P. "Métis: as astúcias da inteligência”. Tradução de F. Hirata. São Paulo: Odysseus, 2008.

72 Trecho da canção: “Gota D’Água”, composta por Chico Buarque para a peça homônima, de 1975, de sua autoria e de Paulo Pontes. A canção foi lançada em vinil em 1977, no álbum homônimo. 
DIAS, R. M. "Nietzsche e Foucault: a vida como obra de arte". (Vol. 1, pp. 41-55). In: KANGUSSU, I. et al. (orgs.). O Cômico e o trágico. Rio de Janeiro: 7 Letras, 2008. DIDEROT, D. "Paradoxo sobre o comediante". Tradução M. S. Chaú́, J. Guinsburg. $2^{a}$. ed. São Paulo: Abril Cultural, 1979. Coleção Os Pensadores.

FOUCAULT, M. "A coragem da verdade: o governo de si e dos outros II". Tradução de E. Brandão. São Paulo: Martins Fontes, 2011.

. "Ditos \& escritos. Ética, sexualidade, política". Tradução de E. Monteiro; I. A. D. Barbosa. $2^{\text {a }}$. ed. Rio de Janeiro: Forense Universitária, 2004. Vol. V.

. "Dits et écrits". Paris: Gallimard, 1994. Vol. IV.

" O governo de si e dos outros. Cursos no Collège de France (1982-1983)". Tradução de E. Brandão. São Paulo: Martins Fontes, 2010.

. "Hermenêutica do sujeito". Tradução de M. A. da Fonseca; S. T. Muchail. São Paulo: Martins Fontes, 2001.

HADOT, P. “O que é a filosofia antiga?” 4a . ed. São Paulo: Loyola, 2010.

LACOUE-LABARTHE, Ph. "A imitação dos modernos: ensaios sobre arte e filosofia". Tradução de J. C. Penna; F. Saadi et al. São Paulo: Paz e Terra, 2000.

NIETZSCHE, F. W. "Sämtliche Werke: Kritische Studienausgabe" (KSA). Orgs. G. Colli e M. Montinari. Berlim; Munique; Nova York: Walter de Gruyter/DTV, 1999. 15 Vol. . "Ecce homo" (EH). Tradução de P. C. Souza. 2ª. ed. São Paulo: Companhia das Letras, 2004.

ONFRAY, M. “A escultura de si”. Tradução de M. Pinheiro. Rio de Janeiro: Rocco, 1995. PALMA, J. L. P. "As (des) Razões da irracionalidade: uma análise conceitual do autoengano, da consciência inconsciente e de outros paradoxos do discurso psicanalítico". 2010. 183f. Tese (Doutorado em Psicologia) - Universidade de Brasília.

PLUTARCO. "Como tirar proveito de seus inimigos; Da maneira de distinguir o bajulador do amigo". Tradução de I. B. B. da Fonseca. São Paulo: Martins Fontes, 1998. . "Obras morais". Tradução de P. B. Dias. Coimbra: Centro de Estudos Clássicos e Humanísticos, 2010.

ROSSET, C. "O real e seu duplo. Ensaio sobre a ilusão”. Tradução de J. T. Brum. Porto Alegre: L\&PM Pocket, 1988.

VAIHINGER, H. “A filosofia do como se". Tradução de J. Krestchmer. Chapecó: Argos, 2011. 